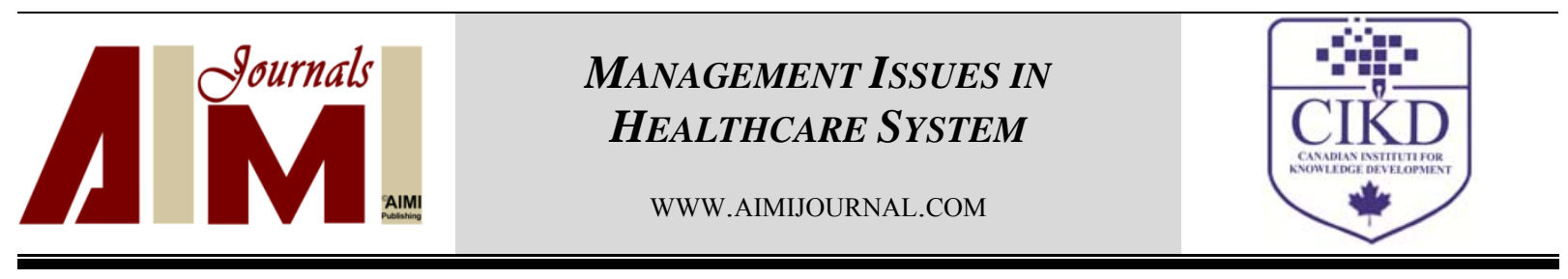

\title{
Do Not Panic! Enhancing Service Recovery of Nursing Services
}

\author{
Maha Mohammed Yusr ${ }^{1 *}$, Mohamad Zainol Abidin Bin Adam, \\ Dayang Nor Saina Bt Azzeni ${ }^{1}$, Wan Mohd Azwan Bin Wan Abaid ${ }^{2}$ \\ ${ }^{1}$ School of Business, Uinversiti Utara Malaysia \\ ${ }^{2}$ KUPB, University Technology Mara Perlis Cooperative Limited
}

\begin{abstract}
Keywords:

Service Recovery, Nursing Service, Top Management Leadership, Commitment, Empowerment, Training, Teamwork

Correspondence: mahayusr@gmail.com

Service recovery has been an important issue due to broader social and economic context that shows greater demand for health, care and support which can be concluded that it is critical to study the health care services. Predicting that factors such as top management leadership, teamwork, empowerment, training and commitment is critical to be understood because all these factors will affect the motivation and attitude of employees toward service recovery. Furthermore, employee is one of the source of sustainable competitive advantage to organisations. Nursing staffs are the ones who have variety of jobs to perform and need to juggle with many jobs at many places in the medical profession. Hence, there is no doubt that failure in their service might occur and service recovery is very crucial to make sure that nurses will perform better in service recovery. This study, therefore, aims to determine the factors influencing service recovery among public nurses. Nurses from various public hospitals in Seberang Perai Utara, Pulau Pinang were chosen as respondents for this study. A total number of 400 questionnaires were distributed to respondents using simple random sampling method. Only 368 questionnaires were returned and used for analysis. The results of correlation analysis and regression analysis have shown that three independent variables (empowerment, training and commitment) had a significant relationship and influenced service recovery. In conclusion, the findings in this study revealed that nurse's commitment is the most critical factors in service recovery.
\end{abstract}

(C)AIMI Journals

\section{Introduction}

Due to the importance of the healthcare sector and the role it plays in the life of the people, the quality of hospital services has been given more attention recently. Therefore, the strategies and related processes to insure the adequacy, the level of the performance, quality improvement, 
and the effective system to control the hospital cost, need to be investigated. Understanding the customers' requirement has become necessary as it supports the decision makers to develop new strategies to provide better service with desired level of quality. Quality is a very critical element concerned by patients while planning to get treatment (Sarwar, 2014).

Hassan, Rahman, and Sade (2015) stated that both public and private sectors of healthcare are supporting each other to provide healthcare services in Malaysia. Although the public sector of healthcare still needs to be improved, the given effort by government so far to enhance the quality of healthcare services in public sector has gained the trust of the people towards public hospitals (Hassan, Rahman, \& Sade, 2015). Healthcare services need to enhance several aspects related to performance. Thus, the performance of the employees in healthcare institutions is one of the critical aspects that affects the overall performance of hospitals. More specifically, the scholars agreed that among others, nursing professionals have a big responsibility to handle and improve healthcare quality service. Therefore, there is need to apply a strategy that can help them to effectively cope with stress, exhaustion, etc. (Othman \& Nasurdin, 2011).

Othman and Nasurdin (2011) argued that nursing professionals highly affected healthcare employees. Nurses are responsible to handle the high demands with targeted level of efficiency, cost cutting, etc., which make their task changeling and complicated. They need to cope effectively with workplace stress, exhaustion and burnout at the same time.

Othman, Ghazali, and Ahmad (2014) discussed that nurses' attitudes and behaviours as customer-contact employees are considered vital in discovering the quality of healthcare services. Andrews-evans (2012) agreed that it is crucial to study how nursing service ensure that their service delivered with desired level of quality, at the same time the processes to recover the failure is going in the same track of overall view of the hospital. However, no research has been reported on how to apply identified factors of service recovery among public nurses in order to bring a change in healthcare services. Public hospitals have received numerous issues compared to private hospitals, thus, it is imperative to detect the factors that affect service recovery among public nurses in Malaysia.

There are changes in a broader social and economic context that results in greater demand for healthcare that call for more studies to figure out the main factors that lead to enhance the healthcare services (Servaty, Krejci, \& Hayslip, 1996). Ashill, Carruthers, and Krisjanous (2005) stated that the key goal of health innovation worldwide is to find the best approach by which the healthcare services will be delivered. However, this condition is not about the health of individuals and communities rather it includes the quality of the healthcare practises. Even though the healthcare system has committed by performances in the past, there is the evidence that shows healthcare system is not working well enough for both, those it serves, and includes the personnel who work in it. The rate of change have been continuing until now (Michael Villenueve, 2006).

Reviewing literature reveals that it is important to figure out the factors that help to prevent or recover failure in nursing service. However, the studies that have been conducted are still limited. Moreover, the lack is more obvious in government sector. In Malaysian context, the situation becomes more important as the need for studies is crucial to pinpoint the main elements that help to recover the failure in nursing service. Nursing service is one of the service that labelled as "service that has to do more for less". The fact that serving in healthcare sector giving more burden and persisting pressure, makes it more interesting field to study and 
explore. Therefore, this study investigates the main factors the can help to enhance the service recovery processes among nursing.

Previous research explores the needs to prevent failure among nursing service. This situation in turn aspired the scholars to answer this question: what are the main factors that lead to failure of service? Answering this question will and help to improve the service and safety of the nursing service. However, there is a lack of study that focus on government hospitals. In order to give a better view about service recovery, many previous research have been conducted, and researchers came out with many variables to measure service recovery. According to Piaralal, Bhatti, Piaralal, and Juhari (2016) factors influencing service recovery in the life insurance industry come from three dimensions; human resource management (training, teamwork, rewards and empowerment), organizational (customer service orientation and top management commitment), and personal (role ambiguity, role conflict, affective organizational commitment and emotional exhaustion). However, findings of a research by Ardahan (2007) showed that several factors such as education, team work and role ambiguity as frontline job perceptions were found to have a positive influence on the service recovery, nerveless, empowerment, reward, and organizational commitment established negative effects on the service recovery. Hence, the purpose of this study is to complement existing research on service recovery among public nurses in Malaysia.

\section{Service Recovery}

Andreassen (2000) stated that service recovery is all about the acts a provider shows in order to overcome dissatisfaction among the customers. Besides, service recovery is also used as a reaction towards low service quality. There are three categories of service recovery. Firstly, the purpose of service recovery is to achieve customer satisfaction to improve the process and for the need of internal marketing strategy (Li, 2010). However, Daskin (2016) noted that the most critical element in the service sector is the service provider itself. Thus, in order to motivate and retain the employees satisfied service, companies really need to understand what the employees expect from the company to do for them.

Hoffman, Kelley, and Rotalsky (1995) agreed that todays' customers are more assertive, educated and more demanding when problems occur. Consequently, this may happen because of the increasing in customers' demand for value generated by services and products they purchase. Besides, the results for customer demands for value lead to emphasis on a blend of reasonable price, decent service and accepted level of quality in the purchases they make. However, a study conducted by Ennew and Schoefer (2003) showed that it is inevitable to avoid service failure completely in any organization. Service failure can occur when service organization fails to convey the service as an individual customer's expectations.

Ashill et al. (2005) identified factors such as empowerment, teamwork, role ambiguity and organizational commitment as the main predictors of service recovery. Accordingly, top management of healthcare institution needs to set up and apply suitable policies within the organization in order to enhance the mentioned predictors. The author further explains that factors (i.e., employee empowerment, education/training and role responsibilities) are among the policies/factors that will enhance the service orientated environment and service recovery performance. Hence it is important to clearly investigate the factors of service recovery in a public healthcare sector. In this regards, empowerment, teamwork, role ambiguity and 
organizational commitment have been identified as the significant prerequisite of service recovery performance by frontline staff. This indicates that top management of healthcare needs to explicitly tailor and build up several conducive organizational policies in order to stablish a structure that can enhance service orientated environment and service recovery performance. The theoretical framework of this research is shown in Figure 1 which shows the variables that need to be studied.

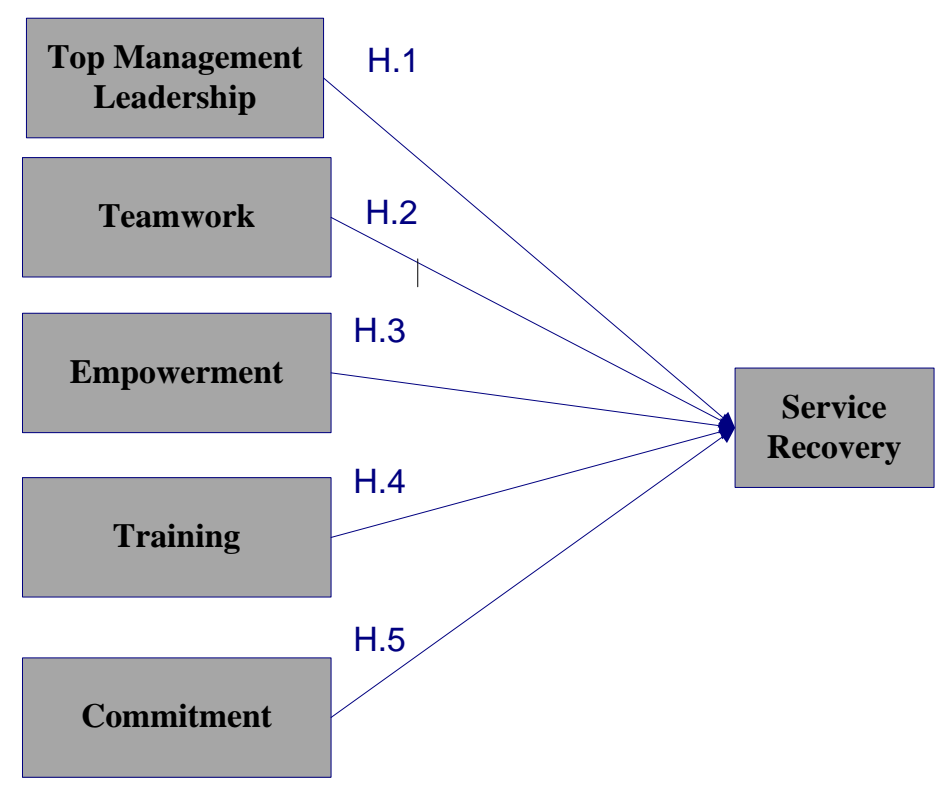

Figure 1. Theoretical framework of the research

\section{Top Management Leadership}

According to Kottke, Pelletier, and Agars (2013), leadership within the context of follower perceptions is a social construction and they are likely to influence their behaviours. There is also common consent that leadership is an approach to guide the individual or group processes in efforts to achieve a particular goals. Tripathi, Prabhakar, and Liffle (2015) stated that the only definition of a leader is a person who has followers. Organizations' long-term goals allow organizations more time to discuss a vision and the outcome, while strong cultures make them a "special place to work". Managers do not need to build their character through recruiting and retaining people who already shared the core values (Kantabutra, 2011).

Zwikael (2008) mentioned that higher level of project success can be gained with extra contribution of top management practiced in an organisation. However, it is essential to determine the effective processes the can support different projects scenarios while there is executive limited resources and time. Previous researchers suggested a framework for leadership development which is adaptable in that the author draws variance between "management development", "leader development" and "leadership development". Some scholars also argue that management development has mainly a training orientation, distinguishing it as the application of proven solutions to known problems. Furthermore, leadership development is a more collective process toward building capacity in anticipation of 
unforeseen challenges whereas leader development focuses on fostering the individual to think and act in new ways (McGurk, 2009).

Based on previous research such as Daskin (2016), leadership has been known as the prerequisite that positively impacts on ethical climate and service recovery. Therefore, several leadership styles have been adopted to create motivated working environment. Furthermore, the leadership attitude to engaging employees in making decision processes encourages employees to be more initiative and more responsible towards service recovery processes.

$\mathbf{H}_{3 \mathbf{a}}$ : There is significant relationship between top management leadership with service recovery

\section{Teamwork}

According to Adebanjo and Kehoe (2001), teamwork and customer focus on critical features of total quality. Identification of management impulse and team efforts are critical in attracting employees to engage in teamwork. The most familiar rationale for failure of employees to participate in teamwork is negative influence of company politics and lack of time.

Teamwork is not the cure for problems in organization. However, bad implementation of teamwork destroys decision rights and individual responsibility while autocratic management has used teamwork as a camouflage (Nurmi, 1996). The establishment of teamwork indicates an action toward a smoother structure through more empowered staff. The concepts of authority and teamwork looks like mutually exclusive, that it may result in corrupts or discourage the others (O'Sullivan, 1996). Besides, Atkinson (2006) stated that the increasing level of involvement by the workplace members is influenced by knowledgeable management that actively support it, at the right time. Positively choosing team players for new staff recruitment, induction processes prioritize team working, and workplace team building activities are then common characteristics.

Research by Ardahan (2007) revealed that team work establishes positive impact on the service recovery. Ashill et al. (2005) identified teamwork as a significant predictors of service recovery, and, therefore, teamwork positively affects organizational performance. However, though teamwork is considered the key approach for solving problems, it is also recognized to be as the source of various failures.

$\mathbf{H}_{3 \mathbf{b}}$ : There is significant relationship between teamwork with service recovery

\section{Empowerment}

Past researches have directly examined the relationship between service quality and employee empowerment (Tsaur, Chang, \& Wu, 2004). Empowerment becomes a critical matter to services sector in general. Therefore, employees and customers must be involved concurrently in the delivery of the service. Quality service is the task taken over by employees; therefore, top management has to provide the employees with necessary support and the authority to succeed at it (Silvia, \& Mazdarani, 2008).

Beirami (2012) mentioned that empowerment is related to job satisfaction which consequently has significant impact on service recovery. By empowering employees, management handover controlling of many sides of the service delivery to frontline employees; 
because of their boundary spanning roles they will be able to deliver fast and appropriate reaction to frustrated customers. In addition, empowerment of employees will enhance the quality of service provided to the customers (Ardahan, 2007).

$\mathbf{H}_{3 \mathbf{c}}$ : There is significant relationship between empowerment with service recovery

\section{Training}

Service provider is more aware about the important role of their employees to deliver the targeted value to the targeted segment in the market. Hence, the awareness about finding suitable employees has increased. However, service provider should not rely on what has been offered in the market, rather they need to create suitable programme to train the employees by which the level of targeted performance will be achieved (Kuemmler \& Kleiner, 1996).

In the service industries, performing a task without sufficient skill jeopardises service quality, and can degrade and embarrass employees (Smith \& Kemmis, 2010). The overwhelming consensus in the literature was that more than any other organization characteristics, an organization's culture was the key to a competitive advantage (Appelbaum $\&$ Fewster, 2004).

In the service companies, training is on top of organizational priorities and innovation in training is one of the most critical parts of the quality improvement. Majority of decision makers believe that the key to success is to have a good training program (Lin \& Darling, 1997). Customer service helps customers deal with more complexity and larger problems. However, if service providers assume that the employees will perform in the best way though they do not know how to do, the customers will pay the short-term price while the company will pay the long-term price if the company lose customers. Therefore, the companies chose to spend more money on training employees to keep current customers or spend more advertising dollars to attract new customers (Bushardt, Fretwell, \& Cumbest, 1994).

According to Shirkhani (2013), designing training program will help employees to perform what they have learned in the best way. Literature in service filed reveals that employees who have not gained particular skills to deal with their tasks will not be able to perform their job successfully and will fail to handle customers' complaints. Previous studies also indicate the significance of customer service training on the satisfaction of employees, which in turn, enhances the employees' skills to handle service failures effectively (Beirami, 2012).

$\mathbf{H}_{3 \mathbf{d}}$ : There is significant relationship between training with service recovery

\section{Commitment}

Customer loyalty has been proven to strongly affect profitability that consequently became a top priority in service industries. However, it is a very difficult task to prevent current customers from switching to other service providers (N'Goala, 2007). Besides, traditional firms now compete with online channels of communication that lead into the changes of nature of the competition between service firms because of the role of the new information and communication technologies (Álvarez, Casielles, \& Martín, 2009). The concept of commitment acts an essential role, as it is a key characteristic of relationship marketing models. 
Commitment points out to an implicit or explicit pledge of the stability of a relationship among the partners (Wetzels, de Ruyter, \& van Birgelen, 1998).

According to previous scholars, employees' performance is one of the main elements and source of competitive advantage of hospital. Therefore, having the right employees can significantly enhance the potential of success of any kinds of organizations ( $\mathrm{He}, \mathrm{Li}, \& \mathrm{Lai}$, 2011; Karatepe \& Olugbade, 2009). However, it is important to acknowledge that employees may show a commitment to achieve quality service without having commitment towards the organization (Worsfold, 1999). In this regards, several studies have concluded that employees' satisfaction is critical output that companies, especially service companies, need to achieve it. The reason behind this is that customers' satisfaction can only be gained if the employees are satisfied. Job satisfaction, moreover, is related to the organizational commitment (Lam \& Qiu Zhang, 2003).

Rod and Ashill (2010) mentioned that workers that are committed to their organizations perform to a higher standard with higher perceived service quality. In the context of service recovery, the more committed the employee is, the more successful the employee should be in addressing service failure.

$\mathbf{H}_{3 \mathbf{e}}$ : There is significant relationship between commitments with service recovery

\section{Methodology}

\section{Sample}

Questionnaires were distributed to nurses of three public hospitals in Pulau Pinang. The questionnaire is used to collect primary data from the respondent (Andrews-evans, 2012). Krosnick (1999) stated that social psychologists are concerned in understanding the way people influence, and how their social environment influences them. The researcher also suggested that survey research can be valuable to other researchers in gathering information. The healthcare industry was considered a suitable context to test this model due to its nature that had high levels of customer contact. Using public nurses was appropriate because the nurses' background here had a range of age with a stable organizational tenure. Other than that, this group of subject also give services to other people and facing various patients' behaviour every day because their job scope is to provide and coordinate patient's health care. Furthermore, most of the nurses have to ensure the service recovery is being handled in the right ways for their daily routine. Hence, it is crucial for health care provider to understand factors that influence the service recovery.

Table 1

Construct Measures and Sources 1

\begin{tabular}{lcl}
\hline Variable & Items & Source and Year \\
\hline Top Management Leadership & 5 & Beirami (2012) \\
Teamwork & 5 & Boshoff and Allen (2000) \\
Empowerment & 5 & Shirkhani (2013) \\
Training & 5 & Boshoff and Allen (2000) \\
Commitment & 6 & Doh (2013) \\
Service Recovery & 8 & Shirkhani (2013) \\
\hline
\end{tabular}




\section{Measurement}

All items were adapted from past studies. In total, 34 scale items were used to count the constructs based on dependent variable and independent variables in the study. This part is to gather information from respondents regarding the factors that impact service recovery performance which are top management leadership, teamwork, empowerment, training, and commitment of the nurses. This survey was conducted using six numerical Likert scale. According to $\mathrm{Wu}$ (2007), in the social sciences field, Likert scale is a favourable tool to measure constructs such as attitudes, images and thoughts. To smoother the analysis of data, each response classification on the scale was generally allocated successively an integer value. The questions were answered by inquiring the respondents to indicate their perceptions or feeling on a scale between two opposing descriptors (agree and disagree).

The nurses from government hospitals in Pulau Pinang (Hospital Daerah Kepala Batas, Hospital Besar Bukit Mertajam, and Hospital Seberang Jaya) were chosen as respondents in this research. The population of all three government hospitals in Pulau Pinang mainland was 4489 nurses. In this study, 400 questionnaires were distributed using convenience random sampling method among public nurses in Penang. The samples of respondent are selected by picking up the respondent based on the name list of the nurses for each department (emergency department, cardiology, intensive care unit, paediatric and etc.) to ensure that the questionnaire was distributed to all respondents.

To ensure that the process of collecting data was efficient, the respondents were provided with information about the research to help them understand the questions while answering the questions. The time provided for the respondent to answer the questions was 15 minutes. The questionnaires were left in the hospitals along with the reference letter for a week and the questionnaires were collected after the period. There were 400 questionnaires distributed and 368 questionnaires were returned and used for analysis.

The data collected was both quantitative and qualitative. The qualitative data was analysed using content analysis. Descriptive and inferential statistics were used to analyse the quantitative data. SPSS software version 20.0 was used for the purpose of data analysis and multiple regression was the approach used to test the hypotheses.

\section{Hypothesis Testing}

Correlation analysis was conducted to achieve Objective 3 of this study. The results of correlation analysis showed that there was no significant relationship between two independent variables (top management leadership and teamwork) towards dependent variable (service recovery). However, the other three independent variables (empowerment, training, and commitment) had a significant relationship with dependent variable (service recovery).

Table 2

Correlation Analysis Result

\begin{tabular}{lr}
\hline Constructs & Service Recovery \\
\hline Top Management Leadership & $.287^{* *}$ \\
Teamwork & $.287^{* *}$ \\
Empowerment & .067 \\
Training & $.293^{* *}$ \\
Commitment & $.420^{* *}$ \\
\hline$*$ Correlation is significant at the 0.01 level $(2$-tailed) & \\
\hline
\end{tabular}

** Correlation is significant at the 0.01 level (2-tailed). 
The results of correlation analysis showed that there was no relationship between top management leadership and service recovery. Thus, H3a was not accepted. According to Shirkhani (2013), leadership is highly related with teamwork. Consequently, it was the same for this study where there was no relationship between teamwork and service recovery. Thus, $\mathrm{H} 3 \mathrm{~b}$ was not accepted. Besides, the results of correlation analysis showed that there was positive relationship between empowerment and service recovery. Thus, H3b was accepted. The result is supported by Rod, Carruthers, and Ashill's (2006) study that shows that commitment exert a positive influence on the service recovery.

Similarly, the results of correlation analysis showed that there was positive relationship between training and service recovery. The positive value of Pearson correlation $(r=.42)$ signifies that the strength of the relationship is moderate relationship. Thus, H3b was still acceptable. The result is supported from a study conducted by Boshoff and Allen (2000) that exhibited acceptable levels of reliability between training and service recovery.

In addition, there was positive relationship between commitment and service recovery. Thus, H3e was accepted. Furthermore, Ashill et al. (2005) also support this result as in their research there was also positive relationship between commitment and service recovery. A research by Beirami (2012) also stated the same result which showed that the commitment was statistically significant and had a positive effect on service recovery.

\section{Discussion}

In this study, the results indicate that only three independent variables significantly influenced service recovery, which are Empowerment, Training, and Commitment. The obtained results, furthermore, are in line with Ashill et al. (2005), where empowerment, teamwork and organizational commitment show a positive impact, while role ambiguity had a negative impact on the recovery processes. Environmental variable (i.e., training), in other side, does not affect the service recovery processes of hospital staff. Moreover, the results of the study revealed that leadership style, neither customer service orientation of the hospital nor rewarding employees for service excellence has any influence on employee service recovery. In the other words, there are many factors can influence service recovery among hospital's staff including nurses.

Furthermore, Rod et al. (2006) mentioned that empowerment, and organisational commitment establish a positive influence, while the environmental variable such as service training does not have a significant impact on the service recovery. Moreover, Masoud and Hmeidan (2013) mentioned that employee training has a positive impact on service recovery. Therefore, it can be concluded that training had a significant effect on service recovery among public nurses in Pulau Pinang which have been supported by the output of this study.

Andrews-evans (2012) mentioned that through a critical nursing science (CNS) reflective approach, one of the main factors contributed to nursing service success is the empowerment. Besides, given autonomy to the nurses enhances the level of control over all practices and business environment they are working in. Based on the results of beta value, the strongest factor that influences service recovery among public nurses is Commitment with Beta value of .41. However, the other two independent variables are not significant to service recovery; Top Management Leadership (-.14) and Teamwork (.08). According to Boshoff and Allen (2000), it seems that organizations want to enhance the service recovery and make sure that they stands 
for organisational commitment to ensure that employees are empowered to solve customer problems. If properly conducted, the improved service recovery will increase the probability the employees that will remain with the firm longer and will be fond of their jobs more.

Table 3

Regression Analysis of Coefficient

\begin{tabular}{|c|c|c|c|c|}
\hline Model & B & $\beta$ & $t$ & $p$ \\
\hline (Constant) & 16.98 & & 6.37 & .000 \\
\hline Top Management Leadership & -.14 & -.09 & -1.91 & .05 \\
\hline Teamwork & .08 & .06 & 1.23 & .216 \\
\hline Empowerment & .14 & .18 & 3.73 & .000 \\
\hline Training & .37 & .31 & 5.93 & .000 \\
\hline Commitment & .41 & .30 & 6.01 & .000 \\
\hline
\end{tabular}

\section{Limitations and Future Studies}

The first limitation of this study is related to the sample of the research. In this study, the questionnaires are only distributed to public hospitals. Even though the participants in the study were selected randomly using simple random sampling, some of the nurses did not participate due to lack of time at the hospitals. Besides, the questionnaires were not distributed to private hospitals because it was assumed that they might have different point of view for each question. The suggestion to overcome the limitation of the study is to broaden the sample of population by distributing the questionnaires to both public and private hospitals. The questionnaires should be distributed early and given longer time so that all respondents that involve in the study can answer the questionnaires especially for respondents that have variance of task and commitment. It can help the results to be more appropriate and accurate.

The second limitation of this study is the location. The location chosen for this study is public hospitals in Pulau Pinang only. Hence, data collected might not necessarily be able to represent the population of the study and the results cannot be generalized across the larger population of nurse in public hospitals. In future, researchers can expend the population for other states in Malaysia to get better understanding about the field. Moreover, more hospitals need to be selected in order to gain more insight of the results. Data collected also may be able to represent the population of the study and the results can be generalized across the larger population.

Lastly, another limitation is related to the gender of the respondents. Most of the respondents are female which count $98.6 \%$ of total number of respondents. Lack of male nurses could have created bias in this study as they might have different views or attitudes to the subject being studied. More male nurses' participation in the study could help to correct this bias. For this limitation, the suggestion is to collect more data from male nurses' perspective. The bias can be corrected if more male nurses could be gathered to answer the questionnaire.

\section{Managerial Implications}

According to the results of this study, it became evident that the main factor influencing service recovery is commitment of the nurses. The main point here is how the organisation can ensure that their employees will have consistent commitment towards their job. The commitment here is covered not only in their own area of service, but across the organisation as a whole.

Every organization should pay more attention towards the need of their employees. Managers need to learn when to adjust their systems by establising justice and fairness in 
promotion and rewards systems of their organization. The management team can also revive the nation of unfairness and emotional stress where employees can upgrade their service performance especially for service recovery and get to take pleasure in positive workplace influences.

Besides, the results of this study show that the highest mean score is 5.14 for item number 2; "I really care about the image of this hospital" for commitment questions. It proved that most respondents felt that the image of the organization they work for is important for them. Thus, the organization should appreciate more on their effort to retain the good image of their workplace. Activities such as family day, potluck event or organizing birthday parties can show appreciation towards the employees.

All these initiatives can motivate the employees to provide and deliver better service in future. Furthermore, it can develop good communication between management and employees, and increase the ability of the employees to act effectively.

\section{Conclusion}

The aim of this study is to identify factors affecting service recovery. The results of this study show that out of five independent variables, three variables (Empowerment, Training, and Commitment) have positive relationship with service recovery among public nurses. Besides, the findings of the study suggest that Commitment is the strongest factor that influences service recovery. Consequently, it shows that nurse will provide better service recovery if they have strong commitment towards their organization. Furthermore, organization should determine ways to increase service commitment among nurses to enhance their ability to deliver service recovery.

Understanding the nature and determinants of service recovery performance is an important and critical issue in evolving and applying service recovery programs. The empirical results of the current study suggest a set of important managerial implications. Commitment, empowerment and training are important prerequisites of service recovery of nursing service in public hospitals. The obtained results recommend that management of healthcare institutions need to tailor and develop several conducive organizational policies. By doing so, service orientated environment will be established and the performance of service recovery will be enhanced. Furthermore, more empowerment helps to have a better service recovery, which suggests that hospital management needs to take an action to give more power and responsibilities to their staffs with the authority to make independent decisions, and give them adequate freedom to assist customers.

In addition, Empowerment and Training also influence service recovery in this study. This finding provides additional evidence to the management team to understand about the perception of their staffs about service recovery. The study, moreover, shows that management team should pay more attention on marketing aspects and increase their understanding in service marketing to provide better quality of service.

\section{References}

Adebanjo, D., \& Kehoe, D. (2001). An evaluation of factors influencing teamwork and customer focus. Managing Service Quality, 11(1), 49-56. https://doi.org/10.1108/09604520110359348

Álvarez, L. S., Casielles, R. V., \& Martín, A. M. D. (2009). The role of commitment perceived by the consumer in service industries. Management Research, 7, 141-157. https://doi.org/10.2753/JMR1536-5433070204 
Andreassen, T. W. (2000). Antecedents to satisfaction with service recovery. European Journal of Marketing, 34(1/2), 156175. https://doi.org/10.1108/03090560010306269

Andrews-evans, M. S. (2012). Learning from failure : An exploratory study of what makes a successful nursing service (Unpublished doctoral disseration). Cardiff University, United Kingdom

Appelbaum, S. H., \& Fewster, B. M. (2004). Safety and customer service : Contemporary practices in diversity , organizational development and training and development in the global civil aviation industry. Management Research News, 27(10), 1-26.

Ardahan, M. G. (2007). The influence of selected antecedents on frontline employee's perceptions of service recovery performance. Hospitality Review, 25(2), 9-32.

Ashill, N. J., Carruthers, J., \& Krisjanous, J. (2005). Antecedents and outcomes of service recovery performance in a public health-care environment. Journal of Services Marketing, 19(5), 293-308. https://doi.org/10.1108/08876040510609916

Atkinson, C. (2006). The total teamwork way. The TQM Magazine, 7(3), 32-34.

Beirami, E. (2012). Total quality management commitment to service recovery performance : an empirical study of front-line hotel employees in the USA (Unpublished master's theis). Eastern Mediterranean University, North Cyprus.

Boshoff, C., \& Allen, J. (2000). The influence of selected antecedents on frontline staff's perceptions of service recovery performance. International Journal of Service Industry Management, 11(1), 63-90. https://doi.org/http://dx.doi.org/10.1108/09564230210447922

Bushardt, S. C., Fretwell, C., \& Cumbest, P. B. (1994). Continuous improvement through employee training. The Learning Organization, 1(1), 11-16. https://doi.org/10.1108/09696479410053395

Daskin, M. (2016). The role of leadership style on frontline employees ' perceived ethical climate, polychronicity and service recovery performance : An evaluation from customer service development perspective liderlik stillerinin müşterilerle yüz yüze irtibatlı çalışanlar. Journal of Entrepreneurship and Innovation Management, 5(2), 125-158.

Doh, W. L. (2013). Antecedents of Service Recovery Performance in 3 and 4 Star Hotels in Douala, Cameroon (Unpublished Doctoral dissertation). Eastern Mediterranean University (EMU), Northern Cyprus.

Ennew, C., \& Schoefer, K. (2003). Service failure and service recovery in tourism : A review, (May). Discussion papers, Christel DeHaan Tourism and Travel Research Institute, Nottingham University Business School.

Hassan, H., Rahman, M. S., \& Sade, A. B. (2015). Contemporary healthcare experience in malaysian hospitals. Journal of Applied Business and Economics, 17(4), 89-94.

He, Y., Li, W., \& Lai, K. K. (2011). Service climate, employee commitment and customer satisfaction: Evidence from the hospitality industry in China. International Journal of Contemporary Hospitality Management, 23(5), 592-607. https://doi.org/10.1108/09574090910954864

Hoffman, K. D., Kelley, S. W., \& Rotalsky, H. M. (1995). Tracking service failures and employee recovery efforts. Journal of Services Marketing, 9, 49-61. https://doi.org/10.1108/08876049510086017

Kottke, J. L., Pelletier, K. L., \& Agars, M. D. (2013). Measuring follower confidence in top leadership direction. Leadership \& Organization Development Journal, 34(4), 292-307. https://doi.org/10.1108/MBE-09-2016-0047

Kantabutra, S. (2011). Sustainable leadership in a Thai healthcare services provider. International Journal of Health Care Quality Assurance, 24(1), 67-80.

Karatepe, O. M., \& Olugbade, O. A. (2009). The effects of job and personal resources on hotel employees' work engagement. International Journal of Hospitality Management, 28(4), 504-512.

Krosnick, J. A. (1999). Maximizing questionnaire quality. Measures of political attitudes, 2, 37-58.

Kuemmler, K., \& Kleiner, B. H. (1996). Finding, training, and keeping best service workers. Managing Service Quality: An International Journal, 6(2), 36-40. https://doi.org/10.1108/20450621211256256

Lam, T., \& Qiu Zhang, H. (2003). Job satisfaction and organizational commitment in the Hong Kong fast food industry. International Journal of Contemporary Hospitality Management, 15(4), $214-220$. https://doi.org/10.1108/09596110310475667

Lin, B., \& Darling, J. (1997). A processual analysis of customer service training. The Journal of Services Marketing, 11(3), 193-205.

Masoud, E. Y., \& Hmeidan, T. A. (2013). The effect of perceived work environment on frontline employee's service recovery performance: the case of four and five star hotels in jordan. European Scientific Journal, 9(11), 129-147.

McGurk, P. (2009). Developing "middle leaders" in the public services? The realities of management and leadership development for public managers. International Journal of Public Sector Management, 22(6), 464-477. https://doi.org/10.1108/MBE-09-2016-0047 
Michael Villenueve, J. M. (2006). Michael Villeneuve and Jane MacDonald. Health (San Francisco). Canada: Canadian Nurses Sociation.

N'Goala, G. (2007). Gilles N'Goala. International Journal of Service Industry Management, 18(5), 510-533.

Nurmi, R. (1996). Teamwork and team leadership. Team Performance Management: An International Journal, 2(1), 9-13.

O’Sullivan, J. (1996). Teamwork is the keystone" say cops. Team Performance Management: An International Journal, 2(3), 23-36. Retrieved from http://dx.doi.org/10.1108/13527599610126247

Othman, N., Ghazali, Z., \& Ahmad, S. (2014). Work engagement in nursing : The role of self-efficacy and, optimism. Paper presented at the Australian Academy of Business and Social Sciences Conference, Kuala Lumpur, Malaysia. http://repo. uum. edu. my/15404.

Othman, N., \& Nasurdin, A. M. (2011). Work engagement of malaysian nurses : exploring the impact of hope and resilience. International Journal of Social, Management, Economics and Business Engineering, 5(12), 395-399. Retrieved from http://citeseerx.ist.psu.edu/viewdoc/download?doi=10.1.1.310.9499\&rep=rep1\&type=pdf

Peters, S. C., \& Silvia, C. P., \& Mazdarani, E. (2008). The impact of employee empowerment on service quality and customer satisfaction in service organizations (Unpublished bachelor thesis). Mälardalen University, Västerås.

Piaralal, S. K., Bhatti, M. A., Piaralal, N. K., \& Juhari, A. S. (2016). Factors affecting service recovery performance and customer service employees: A study of Malaysian life insurance industry. International Journal of Productivity and Performance Management, 65(7), 898-924. https://doi.org/10.1108/MBE-09-2016-0047

Rod, M., \& Ashill, N. J. (2010). Management commitment to service quality and service recovery performance: A study of frontline employees in public and private hospitals. International Journal of Pharmaceutical and Healthcare Marketing, 4(1), 84-103. https://doi.org/10.1108/EL-01-2014-0022

Rod, M., Carruthers, J., \& Ashill, N. J. (2006). Antecedents and outcomes of service recovery performance: insights from an organisation post-corporatisation and post deregulation. Innovative Marketing, 2(2), 20-31.

Sarwar, A. (2014). Healthcare services quality in malaysian private hospitals : A qualitative study. International Journal of Hospital Research, 3(3), 103-112.

Servaty, H. L., Krejci, M. J., \& Hayslip, B. (1996). Relationships among death anxiety, communication apprehension with the dying, and empathy in those seeking occupations as nurses and physicians. Death Studies, 20(2), 149-161. https://doi.org/10.1080/07481189608252747

Shirkhani, S. (2013). Total quality management, commitment, and recovery performance in commercial banks of TRNC (Unpublished doctoral dissertation). Eastern Mediterranean University (EMU), Northern Cyprus.

Smith, E., \& Kemmis, R. B. (2010). What industry wants: Employers' preferences for training. Education and Training, 52(3), $214-225$.

Tripathi, S., Prabhakar, G. P., \& Liffle, J. (2015). Leadership insights from the top: Exploring leadership through the narratives of CEOs in India. International Journal of Leadership, 11(3/4), 126-146. https://doi.org/10.1108/MBE-09-2016-0047

Tsaur, S. H., Chang, H. M., \& Wu, C. S. (2004). Promoting service quality with employee empowerment in tourist hotels: The role of service behavior. Asia Pacific Management Review, 9(3), 435-461.

Wetzels, M., de Ruyter, K., \& van Birgelen, M. (1998). Marketing service relationships: The role of commitment. Journal of Business \& Industrial Marketing, 13(4/5), 406-423. https://doi.org/10.1108/08858629810226708

Worsfold, P. (1999). HRM, performance, commitment and service quality in the hotel industry. International Journal of Contemporary Hospitality Management, 11(7), 340-348. https://doi.org/10.1108/09596119910293240

$\mathrm{Wu}, \mathrm{C}$. H. (2007). An empirical study on the transformation of likert-scale data to numerical scores. Applied Mathematical Sciences, 1(58), 2851-2862.

Zwikael, O. (2008). Top management involvement in project management: A cross country study of the software industry. International Journal of Managing Projects in Business, 1(4), 498-511. Retrieved from https://doi.org/10.1108/17538370810906228 